\title{
REFLECTIONS ON THE REFORM OF THE LEGAL SITUATION OF PEASANTS DURING THE KOŚCIUSZKO UPRISING OF 1794
}

\author{
Marcin Konarski ${ }^{1^{*}}$
}

\begin{abstract}
The aim of this article is to analyse issues related to the reform of the legal status of the rural population during the Kościuszko Uprising, which was the first Polish national uprising. The analysis concerns the fundamental reform of the legal situation of peasants introduced by the uprising authorities in 1794, whose aim was to make this social group join the Uprising. The Commander-in-Chief - Tadeusz Kościuszko - announced the reduction of serfdom loathed by Polish peasants and lifted the ban on leaving the land without the permission of the owner. The defeat of the Uprising destroyed peasants' hopes to be liberated from serfdom. However, it fostered their awareness of being members of the Polish Nation, contrary to the claims of the nobility and the magnates, who considered only their estate to be the Polish Nation and peasants to be their subjects, refusing them the attribute of being Polish.
\end{abstract}

Key words: peasants, Polish-Lithuanian Commonwealth, Third of May Constitution, Tadeusz Kościuszko, Hugo Kołłątaj, Kościuszko Uprising, Supreme National Council, Proclamation of Połaniec, levée-en-masse

\section{INTRODUCTION}

Attempts at reforms - different in nature and scope - of the legal status of peasants were made several times at the end of the $18^{\text {th }}$ century ${ }^{2}$,

1 Doctor of legal sciences - Assistant Professor at the Department of Administration, Faculty of Social Sciences and Administration, Warsaw Academy of Management.

2 See: Celina Bobińska, „Społeczno-ekonomiczne idee polskiego Oświecenia”, Przegląd Historyczny 42(1951): 82-106; Stanisław Śreniowski, „Rzeczpospolita i Galicja w latach 
which, as A. Próchnik stresses, was caused by the fact that many centuries of the manorial system combined with serfdom no longer contributed to economic growth and had led to stagnation and social backwardness ${ }^{3}$. In a well-well known speech in the Convocation Sejm on 16 May 1764, Andrzej Zamoyski emphasised that "the agriculture is collapsing because of the slavery of serfdom, and the taxation against divine law, while in foreign countries it is based on liberty" 4 .

Among reform attempts in this period, worth noting is a draft of a general code known as Zbiór praw sądowych [Collection of court laws], presented in Sejm in 1780 and developed by the above-mentioned A. Zamojski. It established two conditions of peasants: free peasants and przypisańcy - those who have an inheritable right to cultivate their land but who must not leave their land freely5. D. Rolnik stresses that "A. Zamoyski was convinced that improving the situation of peasants would positively affect the development of the Polish Republic" ". Zamoyski's draft gave peasants significant benefits, as it identified and legally protected the class of free peasants and enabled serfd to defend themselves in public courts in the event of serious injustice. This draft, as is commonly known, fell through during clashes in the Sejm but is nevertheless the touchstone of what could be achieved by the most eminent reformers of the peasant issue in the 18 th century ${ }^{7}$.

1772-1795: uwagi o programie politycznym ziemiaństwa polskiego”, Przegląd Historyczny 43(1952): 83-104; Jerzy Michalski, „Propaganda konserwatywna w walce z reformą w początkach panowania Stanisława Augusta”, Przegląd Historyczny 3-4(1952): 536-562; Jerzy Michalski, „Sprawa chłopska na sejmie 1773-1775”, Przegląd Historyczny 45(1954): 3-13.

3 Adam Próchnik, Dzieje chłopów w Polsce, Lviv, 1922, 45.

4 Jerzy Michalski, Sprawa chłopska na sejmie 1773-1775, op. cit.: 4.

5 The course of editorial work on the code is analysed in detail by Józef Broda, Andrzej Zamojski a sprawa chłopska w drugiej połowie XVIII w., Warsaw, 1951, 44-80.

6 Dariusz Rolnik, „Wokół stereotypu magnata czasów stanisławowskich: wizerunek Andrzeja Zamoyskiego (1717-1792) w polskich memuarach", Wieki Stare i Nowe 4(2012): 55.

7 See: Aleksander Świętochowski, Historia chłopów polskich, Poznań 1928, 209. The peasant issue is widely discussed in literature and journalism before 1788, including the works of Stanisław Konarski, Stanisław Leszczyński, Wincenty Skrzetuski, Antoni Popławski, Hieronim Stroynowski, Walerian Stroynowski, Joachim Chreptowicz, Jan Dembowski, Michał Karpowicz and Józef Wybicki as well as texts printed in "Monitor", which was at that time the most progressive journal raising the rural issues and the situation of the rural population, see Położenie chłopów u schyłku Rzeczypospolitej szlacheckiej: 
Echoes of Zamoyski's draft and an attempt to reform Poland's social organisation were included in a passionate book by Stanisław Staszic published in 1785, entitled Uwagi nad zyciem Jana Zamoyskiego ${ }^{8}$, and in Uwagi ogólne nad stanem rolniczym i miejskim z powodu przyszłej rzadu narodowego formy, published in 1789 and probably written by J. Baudouin de Courtenay'. The peasant issue is also the subject of the anonymous Gtos poddan'stwa do stanów sejmujacych and Stanisław Staszic's Przestrogi dla Polski ${ }^{10}$, published in 1790. It is also present in the works of Hugo Kołłątaj ${ }^{11}$, who criticised the feudal system and condemned the exploitation of peasants.

The Four-Year Sejm unjustifiably called a "Polish revolution" by R. Butterwick-Pawlikowski ${ }^{12}$ did not, as is commonly known, decide to

wybór tekstów źródłowych, ed. R. Baranowski, Z. Libiszowska, R. Rosin, Warsaw, 1953, 172-190; Edward Lipiński, Studia nad historią polskiej myśli ekonomicznej, Warsaw 1956, 400-406, 465-475; Edmund Lipiński, Historia polskiej myśli społeczno-ekonomicznej do końca XVIII wieku, Wrocław, 1975, 336-347; Jerzy Michalski, "Wolność” i “własność” chłopska w polskiej myśli reformatorskiej XVIII wieku. Część I”, Kwartalnik Historyczny 4(2003): 5-45; Jerzy Michalski, "Wolność” i “własność” chłopska w polskiej myśli reformatorskiej XVIII wieku. Część II”, Kwartalnik Historyczny 1(2004): 69-103.

8 Stanisław Staszic, Uwagi na życiem Jana Zamoyskiego, Cracow, 1926.

9 Jan Badouin de Courtenay, Uwagi ogólne nad stanem rolniczym i miejskim z powodu przyszłej rządu narodowego formy, Warszawa 1789; Jan Badouin de Courtenay, Ciąg dalszy uwag nad stanem rolniczym i miejskim, In: Materiały do dziejów Sejmu Czteroletniego, published by Jerzy Michalski, Emanuel Rostworowski, Janusz Woliński, Wrocław, 1959.

10 Stanisław Staszic, Przestrogi dla Polski, Wrocław, 2003. Cf. Stanisław Staszic, Ród ludzki, Warsaw 1819-1820, 79-80, 141-142, 233; Władysław Mieczysław Kozłowski, Poglądy filozoficzne Stanisława Staszica, Lublin 1926, 8 ff.; Magdalena Mruszczyk, „Społeczeństwo i państwo z perspektywy „rodu ludzkiego” Stanisława Staszica”, Doctrina. Studia społeczno-polityczne 9(2012): 189-201. For research on the works of Stanisław Staszic, see: Ewelina Tylińska, „Stanisław Staszic w opiniach i badaniach uczonych w II Rzeczypospolitej”, Rozprawy z Dziejów Oświaty 45(2006): 125-133.

11 Hugo Kołłątaj, Do Stanisława Małachowskiego... Anonima listów kilka, Warsaw, 1788, part II, letter of 11 October 1788; Kazimierz Opałek, Hugona Kołłątaja poglądy na państwo i prawo, Warsaw, 1952, 254-255; Hugo Kołłątaj, Prawo polityczne narodu polskiego, vol. II, Warsaw 1954, 200 ff.; Hugo Kołłątaj, Listy Anonima, vol. II, Warsaw, 1954, 61-63; Hugo Kołłątaj, Prawa i obowiązki naturalne człowieka rozwinięte i dowiedzione według wiecznych, niezmiennych i koniecznych praw natury, In: Prawa i obowiązki naturalne człowieka oraz O konstytucji wolności, ed. Hugo Kołłątaj, Warsaw, 2006, 42-54.

12 See: Richard Butterwick-Pawlikowski, "Political Discourses of the Polish Revolution 1788-1792”, English Historical Review 120(2005): 695-731. 
seriously reform the situation of peasants ${ }^{13}$. What the Constitution of 3 May offered in this respect ${ }^{14}$ was very modest, even in the light of temperate demands of Polish journalism in the $18^{\text {th }}$ century ${ }^{15}$.

Article IV of the Constitution was devoted to the legal status of peasants, providing that "the agricultural folk, from under whose hands the most copious source of the country's wealth flows...we accept under the protection of the law and of the national government, and we determine that henceforth whatever liberties, assignments or agreements manorial lords authentically agree to with peasants of their estates, whether those liberties, assignments and agreements be done with groups or with individual inhabitants of a village, shall constitute a mutual obligation, in accordance with the true sense of the conditions and provisions contained in such assignments and agreements, subject to the protection of the national government... We declare complete freedom to all persons, both those newly arriving and those who, having removed from the country, now desire to return to their native land, insofar as every person newly arrived from any part, or returning, to the states of the Commonwealth, as soon as he set foot upon Polish soil is completely free to use his industry as and where he will, is free to make agreements for settlement, wages or rents as and to such

13 Among the demands concerning the reform of the legal status of peasants, worth noting are legal regulations contained in Projekt ad codicem iudiciarium Deputacji do Konstytucji podany by Wojciech Prus Olszowski. Projekt was a competition work created in in connection with the activity at the Four-Year Sejm (1788-1792) aimed at drafting and adopting Kodeks Stanisława Augusta. For more about the competition, see Wojciech Szafrański, Kodeks Stanisława Augusta, Poznań 2007, pp. 168-185. Kołłątaj’s idea, accepted by the Sejm, to announce a competition to write a draft of a new code (or its part) and send it to the deputies - as Wojciech Szafrański writes - aimed at the mass participation of citizens in the work on the reform of the law, see idem, Projekt ad codicem iudiciarium Wojciecha Prus Olszowskiego, Poznań 2008, p. 5. Among numerous competition works, worth noticing is the one by, little known to the historians of law - Wojciech Olszowski written in late 1791 and early 1792.

14 The Government Act of 3 May 1791 (and the Law on Towns of 18 April 1791), Volumina Legum, vol. IX, Cracow, 1889, 214-225 (hereinafter referred to as: VL).

15 This is highlighted by Jan Rutkowski, Historia gospodarcza Polski, vol. I, Poznań 1947, 298, 301-305; see: Emanuel Rostworowski, „Sprawa chłopska w projektach Ustawy Rządowej”, Przegląd Historyczny 4(1960): 732-736; Wojciech Szczygielski, „Rozważania na temat Sejmu Wielkiego (w 220. rocznicę inauguracji obrad)”, Przegląd Nauk Historycznych 2(2008): 55-57. 
time as he agree, is free to settle in city or countryside, and is free to reside in Poland or to return to whichever country he wishes, having previously acquitted such obligations as he had freely taken upon himself"16.

Therefore, the Constitution of 3 May accepted the possibility to conclude a voluntary agreement by a peasant ${ }^{17}$ and guaranteed personal freedom, but only to the newly arrived people and fugitives returning home, which obviously did not have any value for the vast majority of serfs ${ }^{18}$. W. Kamieniecki, bluntly but accurately, called the provisions of the Constitution concerning peasants "humanitarian cliches"19. J. Dihm notices that Article IV of the Constitution gave rise to reservations from the very beginning and that the journalism of the time provides strong evidence that the progressive public opinion wanted to go beyond Article IV and demanded further reform ${ }^{20}$.

\section{THE CAUSES OF THE KOŚCIUSZKO UPRISING}

The origins of the Kościuszko Uprising are obviously connected with the Polish-Russian war, fought by the Poles in defence of the Constitution of 3 May, and by the Russians in defence of magnates' privileges and to put

16 VL, 221. Accepting peasants under "the protection of the law and of the national government" was to apply only to authentic agreements, i.e. agreements formally concluded in writing with manorial lords, which could not be changed by them. However, as Jan Rutkowski notices, "even if, through a broad interpretation, this provision could have been extended by the courts to agreements concluded before the constitution had been adopted, it would have applied, in the first place, to the villages of foreign settlers who arrived in Poland in the $17^{\text {th }}$ and $18^{\text {th }}$ centuries and the small number of Polish villages which had formal privileges”, Jan Rutkowski, Historia gospodarcza..., vol. I, 298.

17 Cf. The remarks of Jędrzej Moraczewski, Włościanin polski ze względu historycznego, statystycznego i politycznego, Poznań, 1844, 23, and Oswald Balzer, Reformy społeczne i polityczne Konstytucyi Trzeciego Maja, Cracow, 1891, 61-62.

18 Jan Rutkowski, Sprawa włościańska w Polsce w XVIII i XIX wieku, Warsaw, $1922,32$.

19 Witold Kamieniecki, „Konstytucya 3 Maja 1791 r. jako reforma państwowa”, Przegląd Historyczny 3(1916): 267.

20 Jan Dihm, „O sprawie chłopskiej, Konstytucji Ekonomicznej i Michale Ossowskim na marginesie uwag Emanuela Rostworowskiego", Przegląd Historyczny 4(1961): 778. 
an end to Polish independence gained during the Four-Year Sejm. This war, which lasted a little over two months, began on 18 May $1792^{21}$, and finished on 24 July 1792, when the "straw man" - the Polish king Stanisław Augustus in the words of Sz. Askenazy ${ }^{22}$ - joined the Targowica Confederation ${ }^{23}$, despite the fact that, according to J. Łojek, the situation of the Republic in the summer of 1792 was such that "continuing to fight the defensive war was definitely justified form the point of view of its basic political interests"24.

In the end, the capitulation of Stanisław Augustus, which later resulted in the third partition, brought the Polish state to the brink of destruction. As A. Zahorski emphasises, "under the rule of the Targowica Confederation and the Russian occupation, Poland suffered terrible ordeal. This ignoble rule, full of violence, targetting awakened national ambitions, stripping Poland of dignity, provoking anger and a desire for revenge, seriously contributed to insurrectionary sentiment" 25 .

Among the initiators of the Uprising ${ }^{26}$, the vision of political changes to be implemented in Poland was very broad. The memorial which Tadeusz

21 The Russian Army attacked Poland with 82 battalions, 156 squadrons, 18 Cossack regiments and 194 cannons, comprising approx. 100000 people. As a result of the superority of the Russians, the Crown and Lithuanian Armies retreated across the Bug River, and after fighting for the Bug River line began to retreat across the Vistula. The period of two months of fighting east of the Bug River was not used by the Commonwealth to strengthen its army - despite the fact that over 10000 recruits were conscripted - which finally led to defeat, see: Tadeusz Rawski, Polska wojna rewolucyjna 1794 roku na tle wojen XVIII wieku, In: VIII Powszechny Zjazd Historyków Polskich w Krakowie 14-17 września 1958. Referaty i dyskusja. VIII. Historia wojskowości, ed. S. Okęcki, Warsaw, 1960,119-120.

22 See: Szymon Askenazy, Dwa stulecia. XVIII i XIX: badania i przyczynki, vol. I, Warsaw, 1901, 314.

23 See: Zofia Zielińska, „Stanisław August, Konstytucja i Targowica: (w związku z pracą Jerzego Łojka, Upadek Konstytucji 3 Maja, Wrocław [etc.] 1976)”, Przegląd Historyczny 2(1978): 317-336; Łukasz Kądziela, „Prymas Michał Poniatowski wobec Targowicy”, Przegląd Historyczny 4(1994): 433-442.

24 Jerzy Łojek, Geneza i obalenie Konstytucji 3 Maja. Polityka zagraniczna Rzeczypospolitej 1787-1792, Lublin 1986, 402.

25 Andrzej Zahorski, Powstanie kościuszkowskie 1794, In: Trzy powstania narodowe, ed. Stanisław Kieniewicz, Andrzej Zahorski, Władysław Zajewski, Warsaw, 1994, 18.

26 The insurrectional conspiracy was established in spring 1793, both in exile and in Poland. The main centre of emigration was Saxony (Leipzig and Dresden). The triumvirate preparing the uprising consisted of Ignacy Potocki, Hugo Kołłątaj and Tadeusz Kościusz- 
Kościuszko brought to Paris in the period of emigration before the Uprising ${ }^{27}$, when he sought help from French revolutionaries, provided that "Taking into account the level of education, old habits and the number of Polish inhabitants which, in the area equal to that of France amounted to only a third of its population, one may conclude that Poles, in a new country yet to be shaped, achieve the results of the French Revolution, by making decisions that: (1) the royal rule is abolished; (2) the Senate, or the upper chamber is abolished; (3) senior clergy is abolished; (4) ordaining

ko. Those who most often joined the conspiracy were most often former members of the Society of the Friends of the Constitution of the Third May, mainly Freemasons, see: Andrzej Zahorski, Warszawa w powstaniu kościuszkowskim, Warsaw 1985, 62-65; Andrzej Zahorski, Powstanie kościuszkowskie..., 171-181. In contrast, King Stanisław Augustus wrote about his role in the Kościuszko uprising in the way which only confirms his anti-national stance, which was already expressed when he joined the Targowica Confederation in 1792: "It happened without me and despite of me", Leon Wegner, "Hugo Kołłątaj na posiedzeniu rady królewskiej z dnia 23 lipca 1792 r.", Roczniki Towarzystwa Przyjaciół Nauk Poznańskiego, vol. V(1869): 49-51. Cf. Adam Skałkowski, Z dziejów insurekcji 1794 r., Warsaw, 1926, 203-220. According to Witold Suchodolski, "One of the first attempts of the King to establish a close contact with the leaders of the uprising was his letter to Kościuszko dated 5 May 1794 in which the King writes that he "shall not seek personal rescue independently of the nation". Witold Suchodolski states that King's behaviour was ambiguous and imprecise, Witold Suchodolski, "Przyczynek źródłowy do roli Stanisława Augusta w wypadkach 1794 r.", Przegląd Historyczny 2(1910): 204-212.

27 For more about the efforts of the Polish emigration to win the support of the authorities of revolutionary France for the independence of Poland and Kościuszko's mission, see Henryk Kocój, Wielka Rewolucja Francuska a Polska. Zarys stosunków dyplomatycznych polsko-francuskich w okresie Sejmu Wielkiego i powstania kościuszkowskiego (problemy wybrane), Warsaw, 1987, 121-123; Henryk Kocój, „W 210 rocznicę powstania kościuszkowskiego", Niepodległość i Pamięć 20(2004): 10. At the end of 1793, F. Barss became the new representative (diplomatic deputy) of Polish emigrants in Paris. He was given the task of reaching the members of the revolutionary government - the Committee of Public Safety - and providing them with information about the course of preparations for anuprising and obtaining help from France, see: Władysław Smoleński, Franciszek Barss (notatka biograficzna), In: Upominek. Książka zbiorowa na cześć Elizy Orzeszkowej (1866-1899), Cracow, 1893, 521-522; Aleksander Kraushar, Barss. Palestrant warszawski i jego misya polityczna we Francji (1793-1800), Warsaw, 1904, 95-96; Marian Kukiel, Próby powstańcze po trzecim rozbiorze, In: Monografie w zakresie dziejów nowożytnych, vol. XIX, Warsaw, 1919, 47; Jean Fabre, Stanislav-Auguste Poniatowski et l'Europe des Lumieres, Paris, 1952, 544; Krzysztof Bauer, Blaski i cienie insurekcji kościuszkowskiej, Warsaw, 1982, 36. 
that every man of any country, estate or religion shall have the freedom to purchase and own land property; (5) that every person owning land property or paying any tax shall have the freedom to elect and be electable for any public function; (6) accordingly, complete abolishment of the serfdom of peasantry, liberty and equal rights for all; (7) the whole nation shall be armed, royal property, every starostwo an the property of clergy shall fund the armed force; (8) all the principles shall be within a week of convening the Sejm, immediately executed and a war with Russia, Prussia and Austria shall begin within two to three weeks" ${ }^{28}$.

How should one interpret this memorial in the context of the situation of Poland at that time? Historiography emphasises the fact that fomenting a national revolution was to lead to a social revolution. A. Próchnik points out that "Kościuszko desired - when the enemies are defeated and on the basis of an armed nation and his profound influence - risk everything so that Poland adopts the political system in accordance with the draft he had presented in Paris. According to to its initiators, the Kościuszko Uprising was to provide grounds for a radical, democratic reform" 29 . However, it is beyond any doubt that all postulates of the peasant reform were subordinate to the overriding goal, i.e. "enabling, at the outbreak of the Uprising, the expansion of the regular army to 100,000 , through the rapid conscription of recruits on an unprecedented scale" 30 .

\section{THE LEGISLATION OF THE UPRISING CONCERNING THE LEGAL SITUATION OF PEASANTS}

\subsection{The issue of peasants' paricipation in levée-en-masse} [pospolite ruszenie]

If one considers the peasant issue during the Kościuszko Uprising, there is no doubt in historiography that the most important document regulating the status of peasantry was the Proclamation of Połaniec, prepared

28 Adam Próchnik, Demokracja kościuszkowska, Lviv, 1920, 71.

29 Ibidem, 73-74.

30 Andrzej Woltanowski, „Tadeusz Kościuszko i pierwszy etap reform włościańskich (28 marca-1 maja 1794 r.)", Przegląd Historyczny 78(1987): 22. 
with the participation of $\mathrm{H}$. Kołłątaj ${ }^{31}$ and announced by the Supreme National Council on 7 May 1794. Obviously, the Commander-in-Chief could not confirm reform only by himself, because the Act of Uprising of 24 March 1794 provided $^{32}$, "that none of the temporary authorities we have established shall, either separately or acting together, be able to adopt acts that would constitute a national constitution. We shall consider any such act to be appropriation of a national self-government, similar to the one against which, with the sacrifice of our lives, we are now fighting" ${ }^{33}$.

According to Point 6 of the Act of Uprising, Commissions for Order to be established in voivodships, lands and powiat districts free of the enemy were to become the only executive tool of the Commander-in-Chief and the Supreme National Council, by executing their orders and ordinances specified in the Act of Uprising ${ }^{34}$. However, as we shall soon see,

31 There is a well-known letter from Kościuszko to the Commission for Order of Kraków Voivodeship of 19 April 1794 in which the Commander-in-Chief informed that Kołłątaj should be treated as his closest collaborator and Kołłątaj’s orders should be treated as if they had been his own, see: Akty Powstania Kościuszki, vol. III, ed. W. Dzwonkowski, E. Kipa, R. Morcinek, Wrocław, 1955, 15; Jerzy Kowecki, Uniwersał Połaniecki i sprawa jego realizacji, Warsaw, 1957, 42; cf. Bartłomiej Szyndler, Powstanie kościuszkowskie 1794, Warsaw, 1994, 160.

32 Akt Powstania obywatelów, mieszkańców województwa krakowskiego 24 marca 1794 r., Archiwum Główne Akt Dawnych, Zbiór Popielów, no. 374.

33 A. Korta once expressed a view that $\mathrm{H}$. Kołłątaj did not think about resurrecting the Constitution of 3 May in liberated Poland. As evidence, he quotes the provisions of the Act of Uprising of 24 March 1794, which announced convening the Constituent Assembly and arranging the principles of a new political system of Poland, see: Adam Korta, "Hugo Kołłątaj", Przegląd Historyczny 42(1951), 21. The anniversary of the Constitution of 3 May was almost unnoticed during the Kościuszko Uprising. According to Zbigniew Góralski, in the Cloth Hall, which was the only place in Kraków where people gathered on that day, the celebration became an anti-royal demonstration, see: Zbigniew Góralski, Stanisław August w insurekcji kościuszkowskiej, Warsaw, 1988, 91. Well-known celebrations of the anniversary of the Constitution of 3 May also included an am anniversary church service in Vilnius, attended by members of the Lithuanian Council and all government deputies, see: Wojciech Bartel, Ustrój władz cywilnych powstania kościuszkowskiego, Wrocław, 1959, 32; Jan Ziółek, Konstytucja 3 Maja: kościelno-narodowe tradycje święta, Lublin, 1991, 65.

34 See: Aleksander Wilkoszewski, „Komisje Porządkowe Koronne za powstania Kościuszkowskiego", Przegląd Historyczny 28(1929), 219; cf. Competencies of the commissions for good order between 1764 and 1790, Tadeusz Srogosz, „Geneza i funkcjonowanie komisji dobrego porządku", Studia z Dziejów Państwa i Prawa Polskiego 2(1995): 152-163. 
Commission for Order of Kraków Voivodeship was averse towards the recommendations of the Commander-in-Cheif concerning his demands of peasant reform ${ }^{35}$.

The first of the proclamations which preceded the Proclamation of Potaniec and which mentioned peasants was the one issued in the camp near Bosutów on 19 April, while one should remember that a few days before - on 14 April - the Commission for Order of Kraków Voivodeship announced the Proclamation concerning the armament of all inhabitants, provision of mounted recruits, drill and armed chase for enemies, ordering the armament of all inhabitants of towns and villages, full alert of those aged 18 to 40 , drafting recruits not only for pedestrian militia but also to create mounted militia, one for every 50 houses and levée-en-masse of all inhabitants under the directions of a manorial lord or a bailiff ${ }^{36}$.

In the proclamation of 19 April (written together with Hugo Kołłątaj) Kościuszko called for slight reduction of serfdom but only for the participants of levée-en-masse ${ }^{37}$, and not all peasants. A general peasant reform was to be carried out at an unspecified time in the future and the limitation of serfdom was to be implemented under the auspices of the Commission for Order, and not the Commander-in-Chief. It is worth remembering, however, that the next day (on 20 April) the Commission for Order of Kraków Voivodeship issued its own "proclamation", which - as emphasised by A. Woltanowski - should be seen as the sabotage of the initiative of Kołłątaj and Kościuszko of 19 April. The reason for this was that "a dominant group of landowners did not agree to even a minimal of serfdom" ${ }^{38}$. The "proclamation" turgidly called on citizens to take care of the families of volunteers and condemned incidents of their oppression.

35 For more about the activities of this Commission, see: Przemysław Jędrzejewski, „Krakowska Komisja Porządkowa w dobie powstania kościuszkowskiego”, Krakowski Rocznik Archiwalny 21(2015): 53-74.

36 Jerzy Kowecki, Pospolite ruszenie w insurekcji 1794, Warsaw, 1963, 81-82.

37 Ibidem, 83-84.

38 The Commission in Kraków consisted of 16 people: seven landowners, two burghers and two clergymen. As Aleksander Wilkoszewski writes "the equal number of representatives of towns and the nobility in the Kraków Commission was the first symptom of equality before the law", Aleksander Wilkoszewski, op. cit., 235. 
Kościuszko's proclamation of Bosutów was supplemented by another one, issued in a camp near Winiary on 30 April or 1-2 May $1794^{39}$. In this proclamation Kościuszko again presented himself as the defender of only those peasants who directly took part in the Uprising, and he recommended that "the Provisional Council in Warsaw and Commissioners for Order in lands and voivodeships across the country immediately issue orders to all manorial lords, leaseholders and bailiffs that they spare each recruit joining the army at least one day of unpaid labour a week, while each voivodeship could be more generous. And levée-en-masse troops, i.e. hunts for the enemy, should be free of labour obligations during the time they spend in the camp. The utmost care should be taken of widows, wives and children of the defenders of Homeland... This is how the people should be made loyal to public affairs and protected against enemy traps". These postulates constituted then an absolute minimum of peasant reform, which was limited to one day reduction of unpaid labour a week and only for recruits.

On 23 May 1794 the Provisional Council issued the Proclamation concerning the non-imposition of the collection of supplies for the army by manorial lords on peasants ${ }^{40}$, which addressed the tendency of manorial lords and leaseholders to impose the collection of supplies on peasants. According to this Proclamation the Provisional Council "strongly recommends that lords and leaseholders of all estates, both laymen and clergymen, do not attempt to impose the collection of supplies, which they are obliged to provide, on peasants. And if they took anything from them, they should return it immediately under pain of appearing in criminal courts if they resist this regulation. The Council recommends that this regulation is executed by the Commission for Order of the Masovian Duchy and the Commission does not only send it to the deputies of powiat and land commissions of the Masovian Duchy but that these deputies send it to parishes and manors and that it is announced to peasants, and that the Commission informs the Council about the effects of this announcement" ${ }^{\text {"41 }}$.

39 See: Uniwersały i rozporządzenia w sprawie chłopskiej z okresu insurekcji kościuszkowskiej 1794 r., Poznań, 1946, 7-9.

40 Akty Powstania Kościuszki: Protokoły i dzienniki Rady Zastępczej Tymczasowej i Rady Najwyższej Narodowej. Part I, ed. Szymon Askenazy, Włodzimierz Dzwonkowski, Cracow, 1918, 191-192 (hereinafter referred to as: APK).

41 Ibidem, p. 192. 
The conscription of peasants was regulated in detail by the Proclamation, following the announcement of the Commander-in-Chief, to the citizens of Poland and Lithuania concerning the delivery of foot and mounted recruits issued by the Supreme National Council in Warsaw on 6 June $1794^{42}$, which ordered readiness in the entire country and codified existing regulations of this form of provisioning armed forces ${ }^{43}$.

According to the Proclamation "One in every five houses should provide a recruit - a young, healthy and fit man with a weapon, i.e. a rifle with several bullets or a 11-foot pike or a vertically fixed scythe and an axe; he should wear peasant clothes, typically worn in villages, and should have two shirts, good shoes, a cap and a thick shirt made from two gores. $\mathrm{He}$ should have enough hardtacks for six days and receive pay for one month, which amounts to 15 złotys" ${ }^{\prime 4}$. Thanks to this system the army received combat-ready and equipped people, which meant that this extremely intensive draft could, from the territory that remained after the second partition, provide about 13000 recruits, including 10000 mounted recruits ${ }^{45}$.

The Proclamation of 6 June was replaced on 18 September 1794 by the more detailed Arrangement concerning the provision by the citizens of one recruit for every 10 houses and one horse for every 50 houses, whose issue the Supreme National Council justified in the following way: "Because levée-en-masse used so far has become less convenient and might become harmful to farms, the Council, following the recommendation of the Chief Commander that the armed forces of Commonwealth should be multiplied in the manner most suitable for defence, possibly the least burdensome for the citizens and with obligations equal for all citizens,

42 Ibidem, pp. 267-269; See also: Jerzy Kowecki, Pospolite ruszenie..., 99 -101. The Supreme National Council was a central government body of national character, in contrast to the Provisional Council which was a local, Warsaw-based body, see: Adam Lityński, Sądy i prawo w powstaniu kościuszkowskim, Wrocław, 1989, 19-24; Jarosław Dudziński, Rada Zastępcza Tymczasowa - pierwszy rząd insurekcji kościuszkowskiej 1794 r.: zarys działalności, Roczniki Humanistyczne 2(2010): 161-201.

43 See: Jerzy Kowecki, Pospolite ruszenie..., 99.

44 APK, vol. I, 268.

45 See: Zdzisław Sułek, Wojskowość polska w latach 1764-1794, In: Zarys dziejów wojskowości polskiej do roku 1864, vol. II (1648-1864), ed. J. Sikorski, Warsaw, 1966, 246. 
decides as follows" ${ }^{26}$. Levée-en-masse thereby ended and was replaced by the draft of recruits ${ }^{47}$.

Z. Sulek points out that as a result of the reduction of the insurgent area in this period the September draft could only provide about 20000 recruits, and mostly covered the poorest inhabitants of towns and villages ${ }^{48}$. At the same time intensive recruitment faced passive resistance of the nobility, which often delayed the release of recruits and those who were provided were ill or handicapped people ${ }^{49}$.

Sanctions for evading the draft were specified in the Proclamation to the citizens avoiding levée-en-masse, establishing punishment for those who are disobedient issued by the Supreme National Council on 7 July 1794. According to the provisions of this Proclamation: "(1) All citizens should join levée-en-masse in accordance with the conditions and descriptions included by the Council in the proclamation of 6 June of this year, except only for those who are exempt by this proclamation; (2) the person who does not fulfil this obligation shall not only be deprived of his property but shall also lose his right to citizenship forever; (3) those who leave and stay abroad without the permission of the government shall be subject to the same punishment; (4) those who stay abroad should return home under pain of the same punishment" 50 .

What is interesting are the arguments of the Council, which passionately indicated historical examples of draft in Poland "Until the 16 th century Poland did not know a regular army but everyone became a soldier in response to a call from the government. Such a soldier spread the boundaries, protected it against the invasion of the neighbours and fought with victorious weapon those who violated rights of nations. When he heard a battle cry to defend Homeland, he hurriedly left his wife, children and home; indeed wives encouraged their husbands, mothers encouraged their sons and in such a way the fair sex had their share in the fame of citizenship. At any time need be, numerous troops were ready. After one call

\footnotetext{
46 APK, vol. II, 171.

47 See: Jerzy Kowecki, Pospolite ruszenie..., 261-263.

48 See: Zdzisław Sułek, op. cit., 246.

49 Ibidem, 246.

50 APK, vol. I, 413-414.
} 
Władysław Jagiełło saw more 100000 soldiers. Kazimierz Jagiellończyk, with more than 200000 volunteers fought a fierce war for 13 years and defeated the might of Teutonic Knight and made them pay tribute. He repelled invasions of Tatars, Czechs and Hungarians. John Casimir with his levée-en-masse beat groups of rebels at Beresteczko ... Poles! Let us be such a nation and tyrants, whose oppression we and our brothers want to be free from, shall not defeat us" ${ }^{\text {" }}$.

Obviously, levée-en-masse was not the main strike force; it cooperated with the regular army and with militia and volunteer units ${ }^{52}$. Its main task was to defend lands and powiat distrcicts against smaller enemy units and to support regular divisions operating in enemy territory ${ }^{53}$. As mentioned before, during the Kościuszko Uprising levée-en-masse comprised all men aged 18 to 40 capable of combat, and consisted of the nobility, peasants and burghers, most of whom were armed with scythes and pikes. Let us add that individual voivodeships created levée-en-masse units ${ }^{54}$, which were under the command of general-majors ${ }^{55}$. Land and voivodeship units consisted of units of individual parishes, commanded by parish cavalry captains and the smallest units were troops headed by manorial lords, bailiffs or wealthier peasants ${ }^{56}$. It should be stressed that all landowners, accompanied with their servants, were obliged to head their troops. Exempt from this duty were only women landowners, clergy and ill or elderly people but on condition that every village provided two mounted substitutes, who were used to complete regular units and militias ${ }^{57}$.

As Z. Sułek emphasizes, levée-en-masse used for armed demonstrations and covering actions rendered significant services, but generally failed during battles, because "incompetently commanded, poorly organised, armed

51 Ibidem, 413.

52 Cf. The speech of Jerzy Kowecki during the discussion on the paper by above-mentioned Tadeusz Rawski, Polska wojna rewolucyjna..., 141, where the author points out that the commanders of levée-en-masse kept demanding such cooperation but in practice could not always count on the assistance of the other strike forces.

53 See: Tadeusz Rawski, op. cit., 148.

54 See: Jerzy Kowecki, Pospolite ruszenie..., 138-259.

55 Ibidem, 132-137.

56 See: Zdzisław Sułek, op. cit., 248.

57 Ibidem, 248. 
and trained masses easily succumbed to panic and usually fled the battlefield"58. Finally, in late September, levée-en-masse was abandoned due to its low combat strength, poor state of agriculture and also growing resistance form the nobility which was averse to the armament of peasant masses and the reduction of labour force ${ }^{59}$.

\subsection{The Proclamation of Potaniec as the basic act of the uprising regulating the legal situation of peasants}

The Proclamation of Potaniec of 7 May 1794, issued in a camp near Połaniec, made reference to Article IV of the Constitution of 3 May where offering peasants the "protection of the law and of the national government" was emphasised. The Proclamation gave this protection a specific form by establishing the institution of custodians [dozorcy] who were to act in disputes between manors and villages ${ }^{60}$.

58 Ibidem, 249. Tadeusz Rawski points out that Kościuszko probably wanted to perceive levée-en-masse as American militia, which in the initial period of the North American war for independence carried the full burden of fighting with the enemy, while at the same time he was aware of different Polish conditions and understood that without the support of troops of the line levée-en-masse could not play a major role in military operations. Furthermore, it could not be an equvalent of American militia because, unlike militias, it consisted of serfs and not free citizens, see: Jerzy Kowecki, Pospolite ruszenie..., $48-51$. It should be remembered that proposals to replace levée-en-masse with militias were already put forward during the Four Year Sejm, see: Emanuel Rostworowski, "Sprawa milicji mieszczańskich w ostatnim roku Sejmu Czteroletniego”, Przegląd Historyczny 4(1955): 561-584. There is no doubt that levée-en-masse units, sensitive to enemy gunfire, were not able to fight in the open field. It should be also added that desertions and escapes from these units were very frequent, although, as Tadeusz Rawski rightly points out, one can hardly use the term "escape" with respect to these units as they were only conscripted for a limited period after which the soldiers returned to their farm work, where nobody could replace them, Emanuel Rostworowski, op. cit., 146-147, 150-151.

59 See: Zdzisław Sułek, op. cit., 249.

60 It should be emphasised that a significant role in the agitation for the Proclamamtion of Połaniec was played by priests, who read out its content in churches, and, as Marek Jaeger emphasises, these sermons were supposed to calm the public feeling and thus prevent revolutionary actions, see: Marek Jaeger, Działalność propagandowo-informacyjna władz powstańczych (1794, 1830-1831, 1863-1864), Lublin, 2002, 227. 
Appeals in disputes were to be settled by Voivodeship Commissions for Order. In the light of the provisions of the Proclamation, custodians became the first government officials in Polish villages. Each custodian was entrusted with a district of 1000 to 1200 farms. Their tasks also included conducting censuses, supervision over the maintenance of roads and bridges, care of the proper development of agriculture and the protection of forests. In addition they were also responsible for the supervision over village teachers who, apart from standard teaching, were supposed to explain government manifestos to peasants and teach them civic duties ${ }^{61}$.

Therefore, for the first time in the history of the Republic, peasants had an opportunity to become members of government bodies at their lowest level. Furthermore, in some voivodesips, for example in Greater Poland, peasants took part in the work of Commissions for Order, that is to say participated in authorities at the voivodeship level. As W. Szczygielski writes, there were demands to introduce peasants to the Supreme National council, i.e. to give them ministerial positions" ${ }^{\text {"62 }}$.

The Proclamation of Potaniec limited the servitude of peasants by granting them personal freedom ${ }^{63}$, which meant a peasant could leave his village under certain conditions, including prior payment of debts to the manor, the settlement of unpaid taxes and a notification to the Voivodeship Commission for Order of the place where he wanted to move ${ }^{64}$. L. Żytkowicz points out that at that time it was understood as the abolishment of serf-

${ }^{61}$ Jan Rutkowski, Uniwersał Połaniecki w świetle europejskich reform rolnych XVIII wieku, Cracow, 1946, 9.

62 Wojciech Szczygielski, Cele lewicy polskiej u schyłku XVIII wieku, Łódź, 1975, 107.

63 In Polish legal studies there is a dispute over the significance of the provisions in the Proclamation concerning the concept of “freedom”, see: Stanisław Śreniowski, „Dwa teksty Uniwersału Połanieckiego”, Państwo i Prawo 3(1947): 50-66; Adam Vetulani, „Jeden czy dwa teksty Uniwersału Połanieckiego”, Państwo i Prawo 10(1947): 27-37. According to Stanisław Śreniowski, the original text of the Proclamation was modified, without the knowledge of the Commander-in-Chief, by the Supreme National Council, and more specifically by Hugo Kołlątaj, in such a way that provisions on the peasants' right to resettle - purportedly not included in the original text - were added. Śreniowski's thesis is disputed by A. Vetulani.

64 Ewa Białynia highlights this fact, wording it as follows: "Before Kościuszko, even during the Great Sejm, resettling a peasant was only allowed with the consent of his lord", Ewa Białynia, Włościanie za Kościuszki, Warsaw, 1922, 23. 
dom and what is more - "that is how these regulations were understood by the insurgent authorities and, after the defeat of the Uprising, by the Russian authorities, as evidenced by numerous manifestos of Russian commanders and the correspondence of Catherine II"65.

When analysing the provisions of the Proclamation one should be aware that despite all their brilliance, they nonetheless limited peasants' rights to immediately enjoy the freedom they had been granted. L. Żytkowicz, quoted above, notices that "under the specific circumstances at that time it seems understandable that the the leadership of the Uprising was afraid of an economic shock, fall in production and undermining the financial basis of the armament effort. However, there is no reason not to consider the Proclamation as a revolutionary reform, undermining the feudal basis of the society and the most far-reaching peasant reform of the $18^{\text {th }}$ century" ${ }^{\prime \prime 6}$.

Apart from granting peasants personal freedom, the Proclamation also guaranteed they could not be evicted from their land, provided they fulfilled their obligations towards the manor. In addition, peasants' labour services towards the manor were to be reduced by $33 \%-50 \%$, where smaller farms, providing less unpaid labour, were granted greater concessions. The principle adopted here was different than the one in the proclamation made in Bosutów, which simply set the upper level of unpaid labour at two days a week. Those who worked for five or six days a week received a reduction of two days (or, respectively, $40 \%$ or $33.3 \%$ ). Peasants who had to work for three or four days were granted a reduction by one day, i.e. $33,3 \%$ or $25 \%$. A reduction of $50 \%$ applied to those who provided unpaid labour services for one or two days a week. For example, in the second half of the $18^{\text {th }}$ century, in the estate of Janów Podlaski on the middle Bug River, a farm with an area of $1 / 4 \tan$ ( 4 ha of arable land) had to provide 250 days of unpaid labour services a year. Larger farms (taking into account the fact that some work, e.g. ploughing had to be done by

65 Leonid Żytkowicz, Czynszowanie i folwark pańszczyźniany w XVII-XIII w. Znaczenie uniwersału połanieckiego, In: Pierwsza Konferencja Metodologiczna Historyków Polskich. Przemówienia, referaty, dyskusja, vol. II, Warsaw 1953, 142.

66 Ibidem, s. 142. Leonid Żytkowicz asks the question whether Kościuszko had a right to ordain such a far-reaching reform, which "so radically undermined the basis of the feudal social structure", pointing out that the Act of Kraków did not give him such power, Leonid Żytkowicz, op. cit., 143. 
two people) provided 500-600 days a year. In Kraków Voivodeship, about $50 \%$ of farms provided $2-4$ days of labour per week, about $10 \%$ provided over two days, $10 \%-4-5$ days and $3 \%$ - five or more days. The remaining farms $(3 \%)$ provided days of labour on the annual basis. Peasants who had to work with their own draught animals usually worked for 5 or more days. Some landowners occasionally sent peasants to work in other estates, which obviously made serfdom even more onerous ${ }^{67}$.

Unfortunately, the proclaimed reforms reduced the obligations of only one category of peasants - serfs - and did dot regulate the status of tenant peasants, whose obligations were not reduced. As J. Kowecki writes "only in one case and only towards on social group the reduction of rent was supported" - the Supreme National Council on 21 June decided to exempt soldiers from the Kurpie region from paying rent for the time of their military service ${ }^{68}$. In addition, we know about an exceptional case of the Lithuanian National Council which extended the interpretation of Kościuszko's proclamation of 2 May by adding an edict that reduced rent proportionally to the reduction of unpaid labour ${ }^{69}$. All in all, peasant reforms during the Kościuszko Uprising only lowered unpaid labour services and did not reduce the amount of rent.

One should mention here Remarks on granting peasants freedom and property, which J. Orchowski submitted to the Supreme National Council in writing ${ }^{70}$. J. Orchowski's Remarks are related to a number of draft peasant reforms, which were often prepared by ordinary citizens. The author of Remarks, as we soon shall see, puts forward and idea that peasants should be granted the property of traitors and emigrants but it also mentioned the obligation of active combat. It should be noted that J. Orchowski's Remarks were primarily intended to indicate to the insurgent authorities how to extend the national uprising; peasants were to play a leading role here. The author presents three ways of extending the uprising. The first

${ }^{67}$ See: Jerzy Topolski, Uniwersał Połaniecki, Lublin, 1994, 8.

68 See: Jerzy Kowecki, „Chłopi czynszowi w reformach Insurekcji 1794 roku”, Przegląd Historyczny 1(1964): 101.

69 Ibidem, 102.

70 See: „Gazeta Rządowa” of 20 July 1794, 77-78: Sessya Rady Najwyższey Narodowej dnia 18 lipca. Prezydencya Ob. X. Franciszka Dmochowskiego, In: Próby reform włościańskich w Polsce XVIII wieku, ed. Stefan Inglot, Wrocław 1952, 230. 
way is as follows: not only a person going to war shall become free but also a father sending two of his sons shall be granted freedom together with his children and their land shall be hereditary property. In order to protect landowners against bankruptcy and so as not estrange indifferent ones, the State treasury shall pay them two parts of the benefits they had from the labour of the liberated peasants. The second way: to provide national land to the nobility which relies on rent. Starostwo districts were already intended in the proclamations of the Commander to be divided between those who take up arms; but the expectation of promise somewhat reduces the allure of hope; it should be approached in this way: a person going to war should enrol in a Commission for Order, which shall guarantee that the starostwo office allocates land for him and his children to be leased by him when he returns. Those escaping from the battlefield, in addition to punishment, shall lose the benefits. The third: to grant peasants property and freedom, but to oblige them to take up arms, in estates owned by traitors, which according to fisci law are intended for the nation. The same should be offered to to the subjects of emigrants who do return to save the Homeland"71.

J. Orchowski's conclusions were welcomed by the Council, which selected a commission (Mostowski, Szymanowski, Bochowiecki) from among its members. Its task was to formulate, on the basis of presented conclusions, a draft that would have a chance to be effectively implemented. It should be noted that Remarks, especially in its second "way" are a revolutionary concept of granting peasants property and freedom in the estates of traitors, a concept which was not formulated in such a radical way even in the Proclamation of Potaniec. The author can be praised for this, as under the Polish conditions of the time putting forward such proposals might have been regarded as revolutionary "Frenchness" 72 .

B. Szyndler points out that "the vast majority of the nobility was against any changes to serfdom and did not want to hear about even very limited reforms aimed at improving the peasants' plight. Lords boycotted subsequent ordinances of the Commander-in-Chief which introduced concessions in serfdom and defended peasants against the oppression of

71 Ibidem, 230.

72 See: Helena Rzadkowska, Stosunek polskiej opinii publicznej do rewolucji francuskiej, Warsaw, 1948, 16, 52-53. 
the manor. Forms of the boycott were varied. Some boldly refused to provide recruits while others brought peasants, sometimes under coercion, to an insurgents' camp themselves"73.

J. Rutkowski noted that the Proclamation of Potaniec was not only the most outstanding and thorough rural reform in the old Republic but it also has a very prominent place among European peasant reforms in the 18 th century due to the "versatility of the reform of different maladies of the agrarian system" "74 and therefore can be explicitly described as the most important agricultural law of the old Republic - so important that its abolishment was one of the first acts of civil authorities of the occupying powers $^{75}$. A. Świętochowski pointed out that the Proclamation of Potaniec was the maximum of what the most progressive nobility allowed but only the minimum of what the good of the nation required ${ }^{76}$.

The Proclamation was nonetheless of significant historical value as it was the first act after the Statute of Wiślica 550 years earlier that did not only see a peasant as a slave, subject or fugitive but gave him legal protection ${ }^{77}$. The same author points out that by incorporating peasants into levée-en-masse and making them the defenders of Poland on a par with the nobility, Kościuszko gave them civic dignity. For the first time - A. Świętochowski wrote - they heard and felt they were recognised as legitimate children of the homeland, which loved them and for whom they have a duty of gratitude ${ }^{78}$.

73 Bartłomiej Szyndler, Powstanie..., 158.

74 Jan Rutkowski, Uniwersał Połaniecki w świetle..., 10.

75 See: Jan Rutkowski, Historia gospodarcza..., vol. I, 299.

76 See: Aleksander Świętochowski, Historia chłopów..., 248. It should also be emphasized that the supporters of the freedom of peasants were also a group of landowners - progressive farmers, striving to intensify production on their farms, which, of course, was not compatible with serfdom, as wage labour ws incomparably better in this respect and as a result attempts to intensify production usually involved the transition form feudal to capitalist economy. "This change - J. Rutkowski writes - would undoubtedly save from going bankrupt or becoming peasants many landowners who had some land and a few subjects but nonetheless were at the verge of petty nobility", Jan Rutkowski, Historia gospodarcza..., vol. I, 300.

77 Aleksander Świętochowski, Historia chłopów..., 248.

78 Ibidem, 249. Mirosław Frančic wrote in a similar tone, pointing out that the Proclamation created a new situation because for the first time peasants came into contact with 
As regards the peasant issue, the legislation of the uprising was not limited to the legal acts mentioned above, i.e. to the law on custody and to the laws which declared personal freedom of peasants and irremovability form land. Hugo Kołłątaj and Polish Jacobins proclaimed ${ }^{79}$, and then implemented, in the form of a resolution of the Supreme National Council of 20 October 1794, the first in the history of the Republic, act of the affranchisement of peasants who took part in the national war, or, if they died in battle, of their successors ${ }^{80}$.

According to point 1 of this resolution "every soldier of the Republic who distinguished himself either because he was wounded when bravely facing the enemy, or because he shall persevere in military service during the present war, shall be rewarded by eternal legacy of land". The next point provides that "Children of those who bravely died when fighting for the Homeland shall receive a reward similar to the one their fathers would have if they were still alive". Point 3 supplemented these provisions by also including those "who shall become wounded and imprisoned and return from prison, or their offspring if they do not return" 81 .

Point 20 concerns orphans of soldiers killed in the war who "shall have the same award of hereditary possession of land, the same as those who persevere until the end of the war". These provisions of the resolution of the Supreme National Council mentioned the "attachment" of peasant soldiers to the homeland whose integrity they defend and about their enduring relationship with the homeland, ensured by the universal ownership of land (point 11) ${ }^{82}$. Everyone rewarded with the ownership of land were obliged to provide military service when the Republic goes to

the idea of a uprising as an obligation towards the homeland and with the concept of an insurgent army, see: Mirosław Frančić, Sprawa chłopska w insurekcji kościuszkowskiej, In: Powstanie kościuszkowskie 1794: z dziejów polityczno-społecznych, ed. Janusz Wojtasik, Warsaw, 1997, 79.

79 For the discussion of the peasant issue in the programme of Polish Jacobins, see: Bogusław Leśnodorski, Polscy jakobini. Karta z dziejów insurekcji 1794 roku, Warsaw, $1960,244$.

80 The text of the resolution was published in "Gazeta Wolna Warszawska” of 25 October 1794, no. 53, 687-690.

81 APK, vol. II, 255-256.

82 Ibidem, 255-260. 
war $^{83}$. Unfortunately, the defeat of the Uprising less than a month later ${ }^{84}$ did not allow Polish peasants to take advantage of the provisions and privileges of this breakthrough legal act.

\section{CONCLUSION}

The army and the mass participation of peasants and burghers in the struggle for Poland's independence during the Kościuszko Revolution were of great importance for the beginnings of the modern nation. The significance of the participation of a large mass of peasants resulted from the atmosphere of the liberation war, from the preparation of the population for the fight and from the insurgent and Jacobin propaganda as well as agitation among the peasants. A. Próchnik once noted that although the major role in the uprising was played by petty nobility and burghers, the participation of a part of the peasantry was proof of "what enormous power could have been achieved if the Uprising had been able to gain the whole class of these oppressed slaves for the defence of the country's independence" 85 .

As A. Śliwiński emphasizes, Tadeusz Kościuszko "realised that the uprising, even if it still had only one powerful superpower against it, must use all available force in order to achieve victory, and that this force will be acquied when the matter of independence becomes a universal aspiration, the aspiration of all layers of the nation" ${ }^{\text {" }}$. All this, along with announce-

83 Ibidem, 259. One should also mention the proclamation of the Department of Instructions of the Supreme Council written by Franciszek Salezy Dmochowski who, developing the thoughts of, among others, Stanisław Konarski, argued the task of a free and independent government it to" create almost a new tribe of Poles, make everyone attached to his Homeland with the strongest ties of the heart and reason”. For more about S. Konarski's views on the peasant issue, see: Stanisław Konarski, O uszczęśliwieniu własnej ojczyzny, In: Pisma wybrane, vol. II, Warsaw, 1955, 343-345, 358-359.

84 See: Jan Kiliński, Pamiętniki, Warsaw, 1958, 215-233; Bartłomiej Szyndler, „Radoszycki finał powstania kościuszkowskiego", Rocznik Muzeum Narodowego w Kielcach 10(1977): 267-284.

85 Adam Próchnik, Demokracja..., 153.

86 Artur Śliwiński, Powstanie kościuszkowskie, Warsaw, 1917, 138. 
ment of reforms, had a decisive effect of peasants, on the their mentality and ultimately their national consciousness.

In 1794 a precedent was created - a tradition and legend was born, which had a tremendous impact on the integration of the nation in the following centuries. Indeed, it was the revolution of 1794 which strengthened and multiplied the achievements of the Polish Enlightenment in the modernisation of the social structure of the nation and of the mental structure of Poles. The first step was taken in the Constitution of 3 May (the term nation appears six times in the aforementioned Article IX) and the revolution of 1794 ensured the next steps towards the creation of the concept of a modern nation and the awareness of its unity to such an extent that Poles were able to survive the partitions and the partitioning powers were not able to deprive them of their nationality.

Peasants were also included in the concept of a nation, despite the fact that the nobility and the magnates, considered only their estate to be a nation ${ }^{87}$. However, as S. Grzybowski notes, "there is no research on the national consciousness of the nobility at the end of the $18^{\text {th }}$ century, we are unable to answer the question what proportion of the nobility had this consciousness" ${ }^{\prime 8}$. Furthermore, there are a lot facts clearly indicating that many most enlightened members of the nobility did not have this consciousness $^{89}$.

Ultimately, what brought beneficial ad-hoc changes to a larger mass of peasant was only the Act on the Sale of Crown Land (Urzadzenie wieczyste królewszczyzn $)^{90}$, which ensured that peasants who settled in these estates had "eternal property rights". i.e., in accordance with the principle of divided property, the property right to use the land and personal freedom, manifested in the possibility to leave the land after the dissolution of the contract with the lord, fulfilment of obligations and the introduction of

87 Helena Brodowska-Kubicz, Świadomość społeczna i narodowa chłopów w Królestwie Polskim w połowie XIX wieku, In: Ksiądz Piotr Ściegienny: epoka, dzieło, pokłosie, ed. Wiesław Caban, Kielce, 1996, 44; Monika Bednarczuk, „Rozumienie narodu i jego profilowanie we współczesnym języku polskim”, Etnolingwistyka 21(2009): 85-101.

88 Stefan Grzybowski, Ojczyzna, naród, państwo, Warsaw, 1977, 98.

89 Ibidem, 98.

90 VL, 424-437. 
another peasant to the farm ${ }^{91}$. The King's influence ensured that peasants had legal protection but it was Hugo Kołłątaj, a more progressive reformer than the King, who added the protection of the government, which opened further legal and administrative possibilities. Further reforms of the legal situation of Polish peasants were introduced by the partitioning powers.

It should also be mentioned that the reform of the legal situation of peasants carried out during the Kościuszko Uprising was obviously much more modest that the reforms in revolutionary France a few years earlier ${ }^{92}$, in that serfdom was limited but the manorial estate was to continue to exist $^{33}$. The former system was modified in a way that was significantly

91 See: Andrzej Stroynowski, „Reforma królewszczyzn na Sejmie Czteroletnim”, Zeszyty Naukowe Uniwersytetu Łódzkiego 69(1979): 53-54, 61 ff; Andrzej Stroynowski, „Metody walki parlamentarnej w toku dyskusji nad reformą królewszczyzn na Sejmie Czteroletnim", Acta Universitatis Lodziensis. Folia Historica 10(1981): 35-48.

92 The reforms mentioned here were introduced by the legislation of the French $\mathrm{Na}$ tional Assembly, announcing on 4-11 August 1789 a number of legal acts which inter alia abolished the feudal servitude of peasants and patrimonial judiciary, see Arrêté du 4 aout 1789 portant renonciation aux privilèges, In: Archives Parlementaires de 1787 à 1860 Première série (1787-1799) sous la direction de Jérôme Mavidal et Emile Laurent. Tome VIII du 5 mai 1789 au 15 septembre 1789, Paris, 1875, 350; Ordre du jour de la séance du 11 aout 1789: discussion sur l'article 7 du projet d'abolition des privilèges, In: Archives Parlementaires de 1787 à 1860 - Première série (1787-1799) sous la direction de Jérôme Mavidal et Emile Laurent. Tome VIII du 5 mai 1789 au 15 septembre 1789, Paris 1875, 394; Discussion sur les articles 7 à 11 du projet d'abolition des privilèges, lors de la séance du 11 aout 1789, In: Archives Parlementaires de 1787 à 1860 - Première série (17871799) sous la direction de Jérôme Mavidal et Emile Laurent. Tome VIII du 5 mai 1789 au 15 septembre 1789, Paris, 1875, 394-396; Décret du 11 aout 1789 relatif à l'abolition des privilèges, In: Archives Parlementaires de 1787 à 1860 - Première série (1787-1799) sous la direction de Jérôme Mavidal et Emile Laurent. Tome VIII du 5 mai 1789 au 15 septembre 1789, Paris, 1875, 397-398; Marie Adopphe Thiers, The History of the French Revolution, London, 1845, 29-35; Adam Szelagowski, Monarchia a rewolucja, Warsaw 1927, 60-66; Adam Szelągowski, Rewolucja Francuska 1789-1793, Lviv 1934, 80-85; Albert Mathiez, Rewolucja Francuska, Warsaw, 1956, 64-70.

93 Just as in previous centuries, the size of manorial farms varied. The size of some of these farms did not exceed the size of larger peasant farms and their organisation was based on the same foundations as in the past, while the role of permanent hired labourers increased. The proper management of the production process moved from manorial farms to demesnes, whose management directly supervised sections of farming that manorial farms were divided into, such as forest management, pond management and bee-keeping. 
beneficial for the peasantry but not abolished completely. There were of course considerable differences between the situation of peasants in France and in Poland. J. Rutkowski emphasises that the system in France was more mature than in Poland for such a fundamental reform ${ }^{94}$.

In France and other European countries feudalism was based on rent. Manorial farms were poorly developed and usually cultivated by hired workforce; unpaid labour had stopped to be common a long time before and, where it still existed, was very limited. As early as in late Middle Ages, peasants who owned land under feudal law were considered owners of the land they cultivated. Treasury acts of the $18^{\text {th }}$ century did not distinguish property of the nobility, Church and peasants. Personal servitude had almost disappeared; serfs could only be found in some provinces and even there they constituted very small minorities ${ }^{95}$. Serfdom no longer restricted personal freedom, but had transformed into a system of fees and other duties for performing activities previously forbidden without the lord's permission. Feudal jurisdiction still existed, but it was so limited by royal jurisdiction that its practical significance was completely unlike the role of patrimonial jurisdiction in Poland and the neighbouring countries" $"$.

Therefore, as we can see, despite the difference between the scale of peasant reforms in revolutionary France and the reforms during the Kościuszko Uprising, the legislation of the French Revolution abolished all feudal burdens, but left a number of burdens, which in French estates were much more important for big landowners. This meant that "peasants-owners whose situation was hitherto better than that of peasants-tenants, who were in a worse position before the Revolution"97.

In latifundia, the lease of manorial farms, with the attached villages and the obligations of their inhabitants, became more widespread, Jan Rutkowski, Historia gospodarcza..., vol. I, 275-277.

94 Ibidem, 310.

95 Jan Rutkowski emphasises that in France personal servitude was very rare, while the attachment to land, formally in force, only slightly limited the freedom to leave the family village, as it was enough to pay the customary fee in order to obtain a resettlement permit, Jan Rutkowski, Historia gospodarcza..., vol. I, 273.

96 Jan Rutkowski, Uniwersał Połaniecki w świetle..., 12.

97 Ibidem, 13-14. 
As regards the relationships between the peasant legislation in Austria and Kościuszko's solutions, J. Rutkowski explicitly points out that the Proclamation of Potaniec gave peasants more that the legislation of Joseph II. What these two reforms had in common was the reduction of obligations, based however on different principles. According to the patents of Joseph II, the farms that benefited the most were large farms of affluent peasants, which provided the highest amount of labour in relation to the farm but the lowest in relation to the arable land they owned, i.e. those that needed relatively small concessions. Farms that provided labour for up to three days a week ${ }^{98}$, which were most encumbered in relation to their area did not gain anything ${ }^{99}$. In contrast, the concessions offered by the Proclamation of Potaniec were the highest for smaller farms and the lowest for the largest farms, which was a solution more beneficial to peasants than the solutions adopted in Austria.

As far as Prussian peasants reforms are concerned, when comparing them with Kościuszko's legislation, we should pay attention to three issues. Firstly, as regards personal freedom, the Proclamation freed all subjects, without any limitation, from the attachment to land with immediate effect, while such a solution appeared in Prussia as late as in $1807^{100}$.

Secondly, it should be noted that in the light of the provisions of the Proclamation irremovability from land was granted to all peasants on the basis of the act itself - so "it was not necessary to conclude individual agreements with lords and to pay ransom, and lords were not exempted from the obligation to help in the event of a natural disaster" ${ }^{101}$.

Thirdly - as J. Rutkowski points out - "as far as obligations are concerned, the Polish act was much more beneficial for peasants than the Prussian legislation of the 18th century. Even as regards the stabilisation of these obligations, the attempts made in various provinces of Prussia were

98 See: Stanisław Schnür-Pepłowski, Z przeszłości Galicji, Lwów 1895, 45; Ireneusz Ihnatowicz, Gospodarka polska od rozbiorów do upadku Księstwa Warszawskiego. Kształtowanie się układu kapitalistycznego, In: Dzieje gospodarcze Polski do 1939 r., ed. Benedykt Zientara, Antoni Mączak, Ireneusz Ihnatowicz, Zbigniew Landau, Warsaw 1965, 311.

99 See: Jan Rutkowski, Uniwersał Połaniecki w świetle..., 17.

100 Stanisław Michalkiewicz, Stosunki społeczne i prawne chłopów do 1807 r., In: Historia chłopów śląskich, ed. Stefan Inglot, Warsaw, 1979, 234-235.

101 Jan Rutkowski, Uniwersał Połaniecki w świetle..., 19. 
not successfully implemented at that time, and Prussia did even start to carry out the general reduction of serfdom, introduced by the Proclamation of Potaniec" 102.

Finally, let us remember that many years after the defeat of the Uprising, Kościuszko's views evolved significantly and did not resemble his views in 1794 . In 1814 he wrote that the liberation of peasants from servitude should be combined with providing them education and their own land ${ }^{103}$. However, just as during the Uprising, Kościuszko treated the implementation of his plan in long-term categories, supporting the noble political system and claiming that peasants were not yet sufficiently prepared to be released from serfdom ${ }^{104}$.

\section{REFERENCES}

Akty Powstania Kościuszki: Protokoły i dzienniki Rady Zastępczej Tymczasowej i Rady Najwyższej Narodowej. Part I. 1918. Ed. Sz. Askenazy, ed. W. Dzwonkowski, vol. I, Kraków.

Akty Powstania Kościuszki. 1955. Ed. W. Dzwonkowski, ed. E. Kipa, ed. R. Morcinek, vol. III, Wrocław.

Askenazy, Szymon. 1901. Dwa stulecia. XVIII i XIX: badania i przyczynki, vol. I, Warszawa.

Badouin de Courtenay, Jan. 1789. Uwagi ogólne nad stanem rolniczym i miejskim z powodu przyszłej rządu narodowego formy, Warszawa.

Badouin de Courtenay, Jan. 1959. Ciąg dalszy uwag nad stanem rolniczym i miejskim, In: Materiały do dziejów Sejmu Czteroletniego, published by Jerzy Michalski, Emanuel Rostworowski, J. Woliński, vol. I, Wrocław.

Balzer, Oswald. 1891. Reformy społeczne i polityczne Konstytucyi Trzeciego Maja, Kraków.

Bartel, Wojciech. 1959. Ustrój władz cywilnych powstania kościuszkowskiego, Wrocław.

102 Ibidem, 19.

${ }^{103}$ See: Tadeusz Kościuszko, Napomknienia względem poprawy losu włościan w dawniejszym Księstwie Warszawskiem, In: Tadeusz Kościuszko, Napomknienia względem poprawy losu włościan i uniwersał połaniecki, foreword by I. Baranowski, Warsaw 1917, 23-29.

104 Ibidem, 28. 
Bauer, Krzysztof. 1982. Blaski i cienie insurekcji kościuszkowskiej, Warszawa.

Bednarczuk, Monika. 2009. Rozumienie narodu i jego profilowanie we współczesnym języku polskim, „Etnolingwistyka” 21:85-101.

Białynia, Ewa. 1922. Włościanie za Kościuszki, Warszawa.

Bobińska, Celina. 1951. Społeczno-ekonomiczne idee polskiego Oświecenia, "Przegląd Historyczny" 42:82-106.

Broda, Józef. 1951. Andrzej Zamojski a sprawa chłopska w drugiej połowie XVIII w., Warszawa.

Brodowska-Kubicz, Helena. 1996. Świadomość społeczna i narodowa chłopów w Królestwie Polskim w połowie XIX wieku, In: Ksiądz Piotr Ściegienny: epoka, dzieło, pokłosie, ed. W. Caban, Kielce.

Butterwick-Pawlikowski, Richard. 2005. Political Discourses of the Polish Revolution 1788-1792, „English Historical Review” 120:695-731.

Dihm, Jan. 1961. O sprawie chłopskiej, Konstytucji Ekonomicznej i Michale Ossowskim na marginesie uwag Emanuela Rostworowskiego, „Przegląd Historyczny" 4(52):775-792.

Dudziński, Jarosław. 2010. Rada Zastępcza Tymczasowa - pierwszy rząd insurekcji kościuszkowskiej 1794 r.: zarys działalności, „Roczniki Humanistyczne” 2:161-201.

Fabre, Jean. 1952. Stanislav-Auguste Poniatowski et l'Europe des Lumieres, Paris. Frančic, Mirosław. 1997. Sprawa chłopska w insurekcji kościuszkowskiej, In: Powstanie kościuszkowskie 1794: z dziejów polityczno-społecznych, ed. J. Wojtasik, Warszawa.

„Gazeta Wolna Warszawska” of 25 October 1794, no. 53.

"Gazeta Rządowa” of 20 July 1794, pp. 77-78: Sessya Rady Najwyższey Narodowej dnia 18 lipca. Prezydencya Ob. X. Franciszka Dmochowskiego, In: Próby reform włościańskich w Polsce XVIII wieku. 1952. Ed. S. Inglot, Wrocław.

Góralski, Zbigniew. 1988. Stanisław August w insurekcji kościuszkowskiej, Warszawa.

Grzybowski, Stefan. 1977. Ojczyzna, naród, państwo, Warszawa.

Ihnatowicz, Ireneusz. 1965. Gospodarka polska od rozbiorów do upadku Księstwa Warszawskiego. Kształtowanie się układu kapitalistycznego, In: B. Zientara, A. Mączak, I. Ihnatowicz, Z. Landau, Dzieje gospodarcze Polski do 1939 r., Warszawa.

Jaeger, Marek. 2002. Działalność propagandowo-informacyjna władz powstańczych (1794, 1830-1831, 1863-1864), Lublin.

Jędrzejewski, Przemysław. 2015. Krakowska Komisja Porządkowa w dobie powstania kościuszkowskiego, „Krakowski Rocznik Archiwalny” 21:53-74. 
Kamieniecki, Witold. 1916. Konstytucya 3 Maja 1791 r. jako reforma państwowa, „Przegląd Historyczny” 3:257-268.

Kądziela, Łukasz. 1994. Prymas Michał Poniatowski wobec Targowicy, „Przegląd Historyczny" 4:433- 442.

Kiliński, Jan. 1958. Pamiętniki, Warszawa.

Kołłątaj, Hugo. 1954. Listy Anonima, vol. II, Warszawa.

Kołłątaj, Hugo. 1954. Prawo polityczne narodu polskiego, part II, Warszawa.

Kołłątaj, Hugo. 2006. Prawa i obowiązki naturalne człowieka rozwinięte i dowiedzione według wiecznych, niezmiennych i koniecznych praw natury, In: H. Kołłątaj Prawa i obowiązki naturalne człowieka oraz O konstytucji wolności, Warszawa 2006.

Kocój, Henryk. 1987. Wielka Rewolucja Francuska a Polska. Zarys stosunków dyplomatycznych polsko- francuskich w okresie Sejmu Wielkiego i powstania kościuszkowskiego (problemy wybrane), Warszawa.

Kocój, Henryk. 2004. W 210 rocznicę powstania kościuszkowskiego, „Niepodległość i Pamięć” 20:9-18.

Konarski, Stanisław. 1960. O uszczęśliwieniu własnej ojczyzny, In: Pisma wybrane, vol. II, Warszawa.

Korta, Adam. 1951. Hugo Kołłątaj, „Przegląd Historyczny” 42:7-25.

Kościuszko, Tadeusz. 1917. Napomknienia względem poprawy losu włościan w dawniejszym Księstwie Warszawskiem, In: T. Kościuszko, Napomknienia względem poprawy losu włościan i uniwersał połaniecki, foreword by I. Baranowski, Warszawa.

Kowecki, Jerzy. 1957. Uniwersał Połaniecki i sprawa jego realizacji, Warszawa.

Kowecki, Jerzy. 1963. Pospolite ruszenie w insurekcji 1794, Warszawa.

Kowecki, Jerzy. 1964. Chłopi czynszowi w reformach Insurekcji 1794 roku, „Przegląd Historyczny" 1:100-103.

Kozłowski, Władysław Mieczysław. 1926. Poglądy filozoficzne Stanisława Staszica, Lublin.

Kraushar, Aleksander. 1904. Barss. Palestrant warszawski i jego misya polityczna we Francji (1793-1800), Warszawa.

Kukiel, Marian. 1919. Próby powstańcze po trzecim rozbiorze, In: Monografie w zakresie dziejów nowożytnych, vol. XIX, Warszawa.

Leśnodorski, Bogusław. 1960. Polscy jakobini. Karta z dziejów insurekcji 1794 roku, Warszawa.

Lipiński, Edward. 1956. Studia nad historią polskiej myśli ekonomicznej, Warszawa.

Lipiński, Edward. 1975. Historia polskiej myśli społeczno-ekonomicznej do końca XVIII wieku, Wrocław. 
Lityński, Adam. 1989. Sądy i prawo w powstaniu kościuszkowskim, Wrocław. Łojek, Jerzy. 1986. Geneza i obalenie Konstytucji 3 Maja. Polityka zagraniczna Rzeczypospolitej 1787-1792, Lublin.

Mathiez, Albert. 1956. Rewolucja Francuska, translated by W. Dzwonkowski, W. Łukaszewicz, T. Landecki, Warszawa.

Michalkiewicz, Stanisław. 1979. Stosunki społeczne i prawne chłopów do 1807 r., In: Historia chłopów śląskich, ed. S. Inglot, Warszawa.

Michalski, Jerzy. 1952. Propaganda konserwatywna w walce z reformą w początkach panowania Stanisława Augusta, „Przegląd Historyczny” 3-4:536-562.

Michalski, Jerzy. 1954. Sprawa chłopska na sejmie 1773-1775, "Przegląd Historyczny" $1(45): 3-13$.

Michalski, Jerzy. 2003. "Wolność" i "własność" chłopska w polskiej myśli reformatorskiej XVIII wieku. Część I, „Kwartalnik Historyczny” 4:5-45.

Michalski, Jerzy. 2004. "Wolność" i "własność" chłopska w polskiej myśli reformatorskiej XVIII wieku. Część II, „Kwartalnik Historyczny” 1:69-103.

Moraczewski, Jędrzej. 1844. Włościanin polski ze względu historycznego, statystycznego i politycznego, Poznań.

Mruszczyk, Magdalena. 2012. Społeczeństwo i państwo z perspektywy „rodu ludzkiego" Stanisława Staszica, „Doctrina. Studia społeczno-polityczne” 9:189-201.

Położenie chłopów u schyłku Rzeczypospolitej szlacheckiej: wybór tekstów źródłowych. 1953. Ed. R. Baranowski, Z. Libiszowska, R. Rosin, Warszawa.

Próchnik, Adam. 1920. Demokracja kościuszkowska, Lwów.

Próchnik, Adam. 1922. Dzieje chłopów w Polsce, Lwów.

Rawski, Tadeusz. 1960. Polska wojna rewolucyjna 1794 roku na tle wojen XVIII wieku, In: VIII Powszechny Zjazd Historyków Polskich w Krakowie 14-17 września 1958. Referaty i dyskusja. VIII. Historia wojskowości, ed. S. Okęcki, Warszawa.

Rolnik, Dariusz. 2012. Wokół stereotypu magnata czasów stanisławowskich: wizerunek Andrzeja Zamoyskiego (1717-1792) w polskich memuarach, „Wieki Stare i Nowe" 4:44-68.

Rostworowski, Emanuel. 1955. Sprawa milicji mieszczańskich w ostatnim roku Sejmu Czteroletniego, „Przegląd Historyczny” 4:561-584.

Rostworowski, Emanuel. 1960. W sprawie Konstytucji Ekonomicznej 1791 r.: (na marginesie książki Jana Dihma), „Przegląd Historyczny” 4:732-736.

Rutkowski, Jan. 1922. Sprawa włościańska w Polsce w XVIII i XIX wieku, Warszawa.

Rutkowski, Jan. 1946. Uniwersał Połaniecki w świetle europejskich reform rolnych XVIII wieku, Kraków. 
Rutkowski, Jan. 1947. Historia gospodarcza Polski, vol. I, Poznań.

Rzadkowska, Helena. 1948. Stosunek polskiej opinii publicznej do rewolucji francuskiej, Warszawa.

Schnür-Pepłowski, Stanisław. 1895. Z przeszłości Galicji, Lwów.

Skałkowski, Adam. 1926. Z dziejów insurekcji 1794 r., Warszawa.

Smoleński, Władysław. 1893. Franciszek Barss (notatka biograficzna), In: Upominek. Książka zbiorowa na cześć Elizy Orzeszkowej (1866-1899), Kraków.

Srogosz, Tadeusz. 1995. Geneza i funkcjonowanie komisji dobrego porządku,

„Studia z Dziejów Państwa i Prawa Polskiego” 2:152-163.

Staszic, Stanisław. 1926. Uwagi na życiem Jana Zamoyskiego, Kraków.

Staszic, Stanisław. 2003. Przestrogi dla Polski, Wrocław.

Staszic, Stanisław. 1819-1820. Ród ludzki, Warszawa.

Stroynowski, Andrzej. 1979. Reforma królewszczyzn na Sejmie Czteroletnim, „Zeszyty Naukowe Uniwersytetu Łódzkiego. Seria 1, Nauki Humanistyczni-Społeczne" no. 69.

Stroynowski, Andrzej. 1981. Metody walki parlamentarnej w toku dyskusji nad reformą królewszczyzn na Sejmie Czteroletnim, „Acta Universitatis Lodziensis. Folia Historica" 10:35-48.

Suchodolski, Witold. 1910. Przyczynek źródłowy do roli Stanisława Augusta w wypadkach 1794 r., „Przegląd Historyczny” 2:204-212.

Sułek, Zdzisław. 1966. Wojskowość polska w latach 1764-1794, In: Zarys dziejów wojskowości polskiej do roku 1864, vol. II (1648-1864), ed. J. Sikorski, Warszawa.

Szafrański, Wojciech. 2007. Kodeks Stanisława Augusta, Poznań.

Szafrański, Wojciech. 2008. Projekt ad codicem iudiciarium Wojciecha Prus Olszowskiego, Poznań.

Szczygielski, Wojciech. 1975. Cele lewicy polskiej u schyłku XVIII wieku, Łódź. Szczygielski, Wojciech. 2008. Rozważania na temat Sejmu Wielkiego (w 220. rocznicę inauguracji obrad), „Przegląd Nauk Historycznych” 2:5-60.

Szelągowski, Adam. 1927. Monarchia a rewolucja, Warszawa.

Szelągowski, Adam. 1934. Rewolucja Francuska 1789-1793, Lwów.

Szyndler, Bartłomiej. 1977. Radoszycki finał powstania kościuszkowskiego, „Rocznik Muzeum Narodowego w Kielcach” 10:267-284.

Szyndler, Bartłomiej. 1991. Tadeusz Kościuszko 1746-1817, Warszawa.

Szyndler, Bartłomiej. 1994. Powstanie kościuszkowskie 1794, Warszawa.

Śliwiński, Artur. 1917. Powstanie kościuszkowskie, Warszawa.

Śreniowski, Stanisław. 1947. Dwa teksty Uniwersału Połanieckiego, „Państwo i Prawo" 3:50-66. 
Śreniowski, Stanisław. 1952. Rzeczpospolita i Galicja w latach 1772-1795: uwagi o programie politycznym ziemiaństwa polskiego, "Przegląd Historyczny" 43:83-104.

Świętochowski, Aleksander. 1928. Historia chłopów polskich, Poznań.

Thiers, Marie Adolphe. 1845. The History of the French Revolution, London.

Topolski, Jerzy. 1994. Uniwersał Połaniecki, Lublin.

Tylińska, Ewelina. Stanisław Staszic w opiniach i badaniach uczonych w II Rzeczypospolitej, „Rozprawy z Dziejów Oświaty” 2006, no. 45, pp. 125-133.

Uniwersały i rozporządzenia w sprawie chłopskiej z okresu insurekcji kościuszkowskiej 1794 r. 1946. Poznań.

Wegner, Leon. 1869. Hugo Kołłątaj na posiedzeniu rady królewskiej z dnia 23 lipca 1792 r., „Roczniki Towarzystwa Przyjaciół Nauk Poznańskiego”, vol. V:1-68.

Wilkoszewski, Aleksander. 1929. Komisje Porządkowe Koronne za powstania Kościuszkowskiego, „Przegląd Historyczny” 2(28):219-286.

Woltanowski, Andrzej. 1987. Tadeusz Kościuszko i pierwszy etap reform włościańskich (28 marca-1 maja 1794 r.), „Przegląd Historyczny” 1(7)8:19-44.

Vetulani, Adam. 1947. Jeden czy dwa teksty Uniwersału Połanieckiego, „Państwo i Prawo" 10:27-37.

Volumina Legum, vol. IX, Kraków 1889.

Zahorski, Andrzej. 1985. Warszawa w powstaniu kościuszkowskim, Warszawa.

Zahorski, Andrzej. 1994. Powstanie kościuszkowskie 1794, In: Trzy powstania narodowe, ed. S. Kieniewicz, ed. A. Zahorski, ed. W. Zajewski, Warszawa.

Zielińska, Zofia. 1978. Stanisław August, Konstytucja i Targowica: (w związku z pracą Jerzego Łojka, Upadek Konstytucji 3 Maja, Wrocław [etc.] 1976), „Przegląd Historyczny” 2(69):317-336.

Ziółek, Jan. 1991. Konstytucja 3 Maja: kościelno-narodowe tradycje święta, Lublin.

Żytkowicz, Leonid. 1953. Czynszowanie i folwark pańszczyźniany w XVII-XIII w. Znaczenie uniwersału połanieckiego, [w:] Pierwsza Konferencja Metodologiczna Historyków Polskich. Przemówienia, referaty, dyskusja, vol. II, Warszawa. 